مقاله

يُروهشى

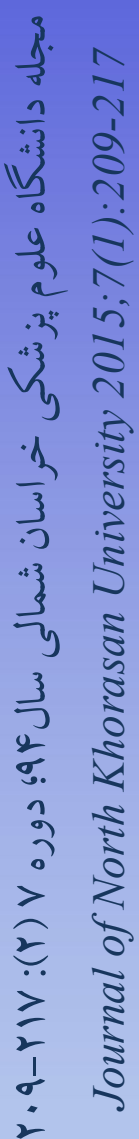

وصول: •

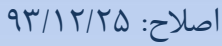

يذيرش:

بررسى نقش تعديل كننده تي هاى شخصيتى در رابطة بين رفتار سياسى مديران و رفتارهاى ضلشهرونلى كار كنان دانشعاه علوم يزشكى مشهد

\author{
حميد تابلى '، عبدالله ريحانى يساولى آ" \\ 'دانشيار بخش مديريت دولتى دانشكاه بيام نور

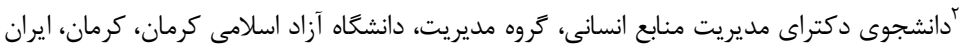

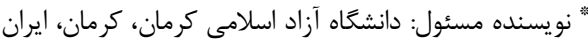 \\ يست الكترونيك:Reihanyya1@mums.ac.ir
}

جكيده

زمينه و هدف: دانشكاه علوم بزشكى يكى از مهم ترين اركان خدمت رسانى به شهروندان مىباشد و هدف

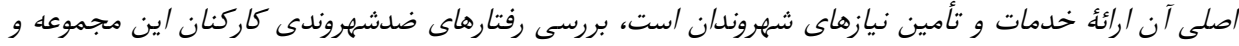

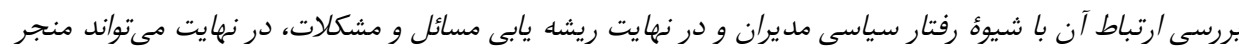

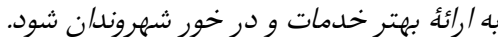
مواد و روش كار: بزوهش حاضر اين بزوهش از لحاظ ماهيت توصيفى از نوع تحليل همبستىى و از لحاظ

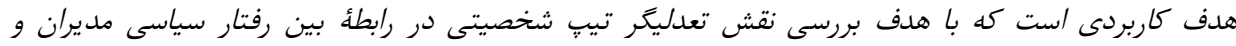

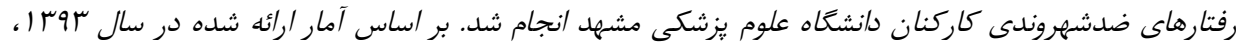

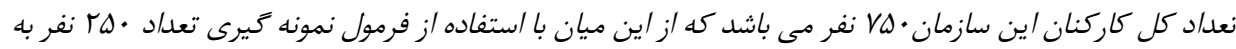

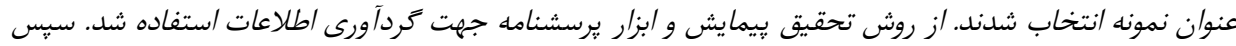

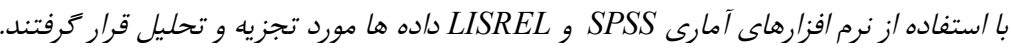

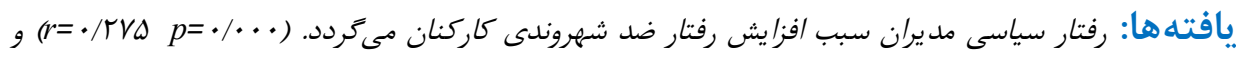

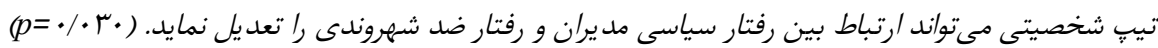

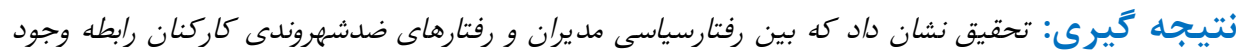
دارد؛ بدين ترتيب كه رفتار سياسى مديران سبب افزايش رفتارهاى ضدشهروندى كاركنان مى بشود. از ميان ابعاد

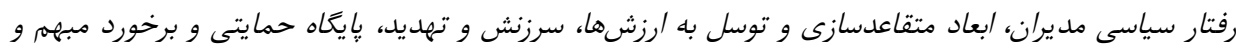

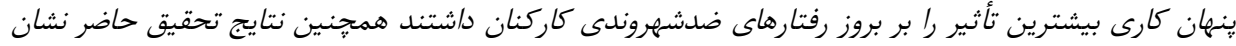

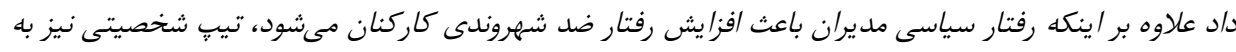

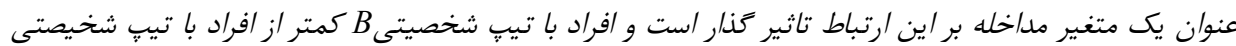
A تحت تاثير رفتار سياسى مديران دست به به رفتار ضد شهروندى مىزنند.

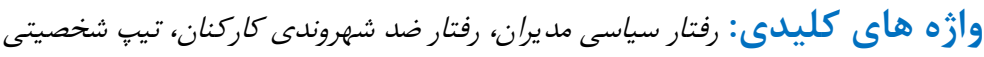


خدمات و تأمين نيازهاى شهروندان است، بررسى

رفتارهاى ضدشهروندى كاركنان اين مجموعه و بررسى بـات

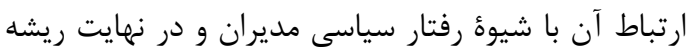

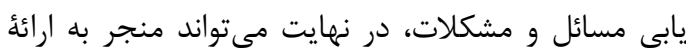
بهتر خدمات و در خور شأن شهروندان شود. بنابراين اين تحقيق مىتواند از طريق بررسى رفتان

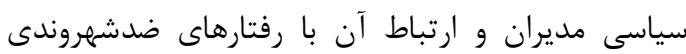

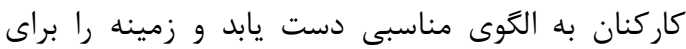
شيؤ مديريت صحيح و بروز رفتارهاى شهروندى سازمانى

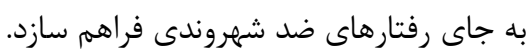

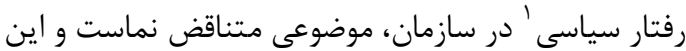
توصيه به مديران كه جكونه سياستمدار باشند غالبا توصيه

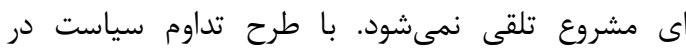
سازمان نتيجه مى

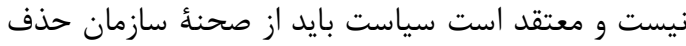

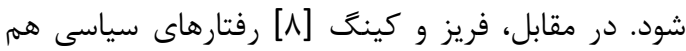

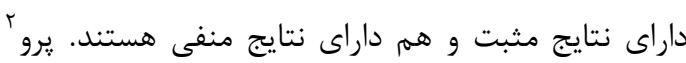

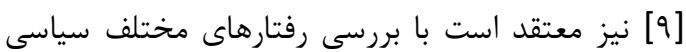

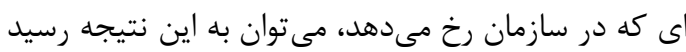

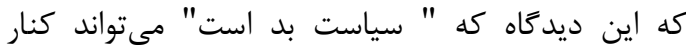
كذاشته شده و ناديده انخاشته شود؛ زيرا رفتارهاى سياسى آدى

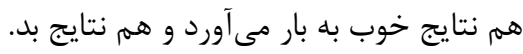
بدين ترتيب اين به نحوهٔ مديريت بستكى دارد كه از جنبه هاى مثبت سياست در مديريت در سازمان استفاده كند و

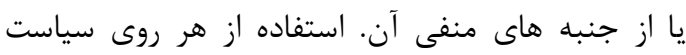

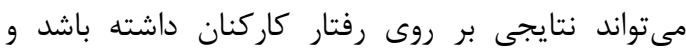
واكنش هايى از سوى آنها داشته باشد روند

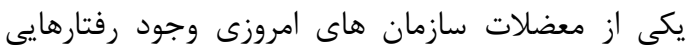

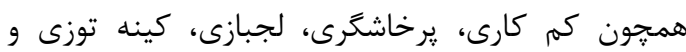

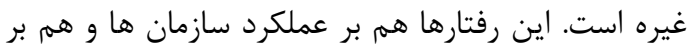

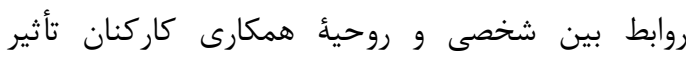

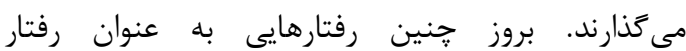

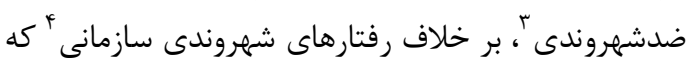
موجب ارتقاى عملكرد سازمان، اثربخشى سازمان، رضايت ناني

1- Political Behavior

\section{2- Perrewe}

3- Anti -Citizenship behavior

4- Organizational citizenship behavior
سازمان ها جامعهُ امروزى را تشكيل مىدهند. بخش عمده

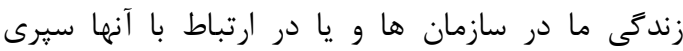

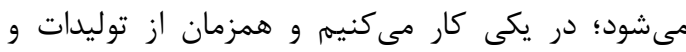
خدمات سازمان هاى ديخر استفاده مى كنيم. هر سازمان با انجام دادن وظايف مختلف، هدف هاى متفاوتى رأ براى داى دان

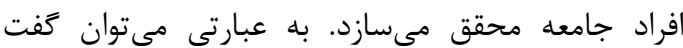

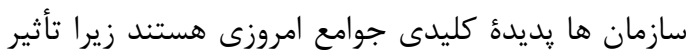

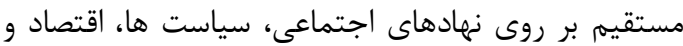

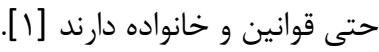
קكونكى به كاركيرى سياست از جانب مديران نقش بسزايى در رفتار و همجنين احساس كاركنان دارد. يك مدير مى تواند با بكاركيرى درست استراتزى هاى سئ سياست در كارمندان انخيزه كار ايجاد كرده، اعتماد را بالا برده و وائري بهره ورى نيروى انسانى را افزايش دهد. عكس اين قضيه

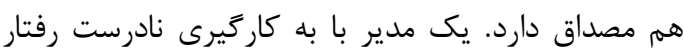
سياسى مى تواند موجبات نارضايتى كار كنان را فراهم كرده و باعث شيوع رفتارهاى نادرست و ضدشهروندى سارى سازمان

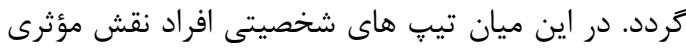

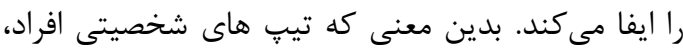
رفتارهاى متفاوتى را ايجاد مى كند. بنابراين در رابطؤ بين رفتار سياسى مديران و رفتارهاى ضدشهروندى مديران إنان بايد به نقش تيب هاى شخصيتى افراد توجه كرد.

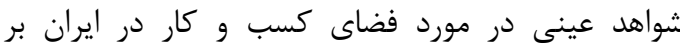
اهميت رفتارهاى سياسى و بازخوردها و نتايج آن تأكيد مى كند. مطالعات نشان مىدهد نظام ادارى حاكم بر فرهنَ كسب و كار ايران به رغم پِيشينه تاريخى، فاقد

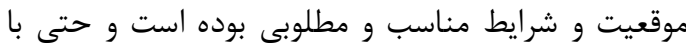

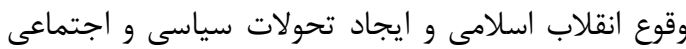

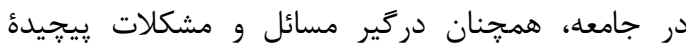

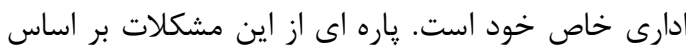

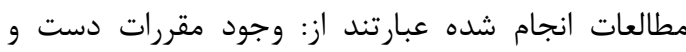

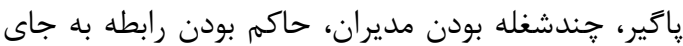
ضابطه، پائين بودن سطح بهره ورى، تأكيد بر منافع فردى برى راكي

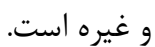
از آنجايى كه دانشخاه علوم يزشكى مهرم ترين اركان

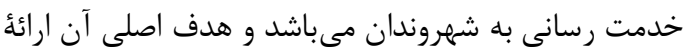


T)مهم ترين رفتارهاى سياسى مديران از ديدَاه كاركنان

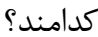

(ب) آيا ادارك كاركنان از رفتار سياسى مديران بر رفتارهاى

ضدشهروندى كاركنان تاثير كذار است؟

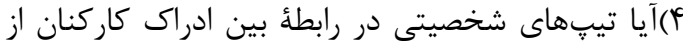

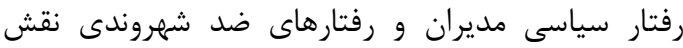

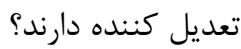

\section{روش كار}

اين يزوهش از لحاظ ماهيت توصيفى از نوع تحليل

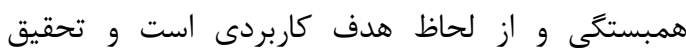
كاربردى تحقيقى است كه هدف آن توسعه دانش كاربردى آرى لهات در يك زمينه خاص است. به عبارت ديخر تحقيقات

كاربردى به سمت كاربرد علمى دانش هدايت مى شوند. با توجه به اينكه هدف اصلى در اين تحقيق سنجش نكرش

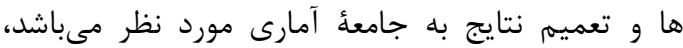

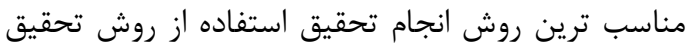

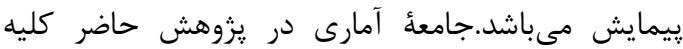
كاركنان سازمان مركزى دانشكاه علوم يزشكى مشهيد در

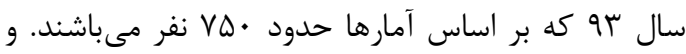

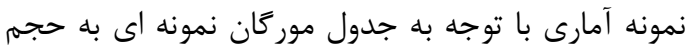

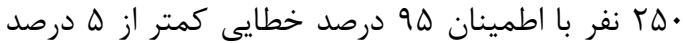

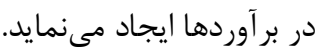
با توجه به عدم همَنى نظرات در معابِ معاونت هاى هر معاونت به عنوان يك طبقه در نظر كرفته شده است از روش نمونه كيرى طبقه اى با تخصيص متناسب استفاده شده است.

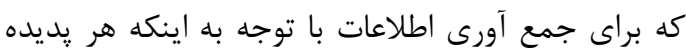

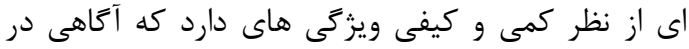

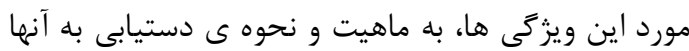
وابسته است. هدف هر تحقيقى اعم از توصيفى يا تبيينى، دستيابى به اطلاعات در مورد اين تغييرات است. يافتن ياسخ و راه حل براى مساله انتخاب شده در هر تحقيق،

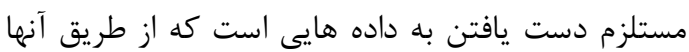
بتوان فرضيه هايى كه به عنوان ياسخ هاى احتمالى و موقتى براى مساله تحقيق مطرح شدهاند را آزمون كرد. در

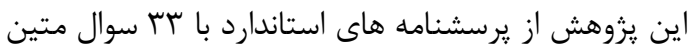
زارعى براى رفتار سياسى مديران و يرسشنامه ها سوال رابينسون و بنت براى بررسى رفتارهاى ضد شهار شرياس بروندى و
و وفادارى مشترى و غيره مىشود، مىتوانند مانع كاركرد

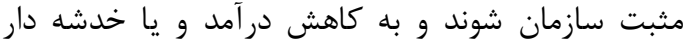

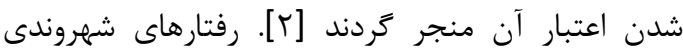

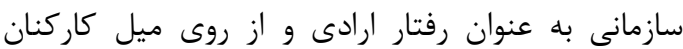
تعريف مىكردد كه داوطلبانه بوده و نوعاً به آنها رياداش تعلق نمى گيرد اما مى توانند عملكرد سازمان را بهيبود بخشند [ب]. برعكس، رفتارهاى ضد شهروندى دامنهُ گسترده ایى از

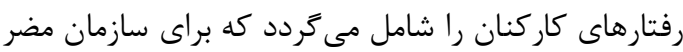
مىباشند. سرقت، غيبت، كينه توزى و تخريب اموال از از

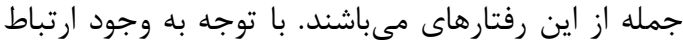

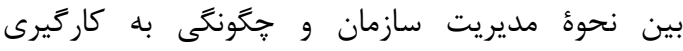

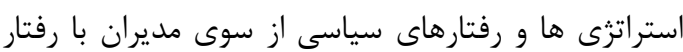

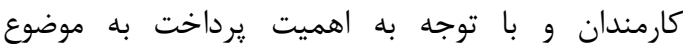
رفتارهاى ضدشهروندى در سازمان ها كه موجب يايين

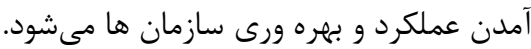
از طرفى يكى از متداول ترين طبقه بندىهايى كه روانشناسان براى شخصيت به كار مىبرند تيب شخصيتى

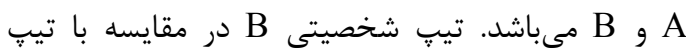
شخصيتى A خوددارترند و از بروز احساسات خود بيشتر

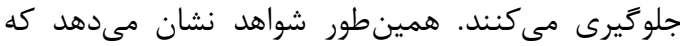
تيب شخصيتى B در ياد ميرى بيشتر تحت تاثير تنبيه قرار

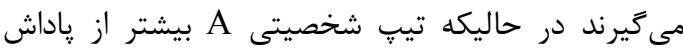

$$
\text { تاثير مى يذيرند [F] }
$$

در يزوهشهاى مشابه ديده شده است كه تيب شخصيتى بر رفتار ضدشهروندى تاثير كذار هستند. و انتظار مىرود

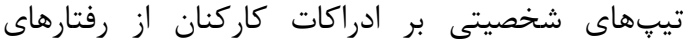

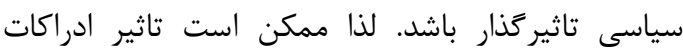
كار كنان از رفتار سياسى مديران بر رفتار ضد شهروندى در تيبيهاى شخصيتى متفاوت باشد.

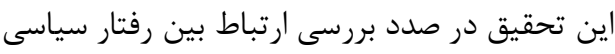
مديران و رفتارهاى ضدشهروندى كار كنان با توجه به نقش تعديلكر تيب هاى شخصيتى مى باشد. بدين ترتيب سوالات مطرح شده در ذيل سوالات تحقيق

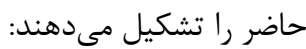
() (رفتارهاى ضدشهروندى كاركنان در ابعاد مختلف آن به جه ميزانى است؟ 


\section{كافته ها}

متوسط سن קاسخكويان بr سال بوده است كه اكثر آنها

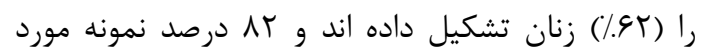
بررسى متاهل مىباشند. متوسط سابقه كارى ياسخكَويان

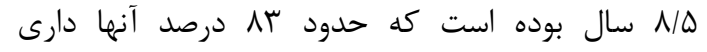

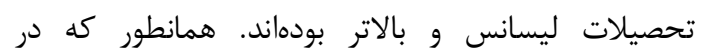

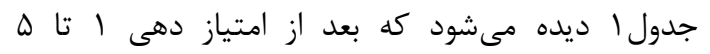

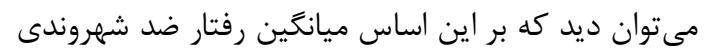

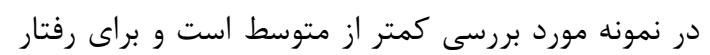

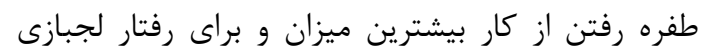

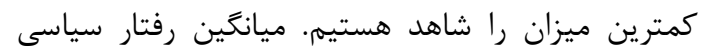

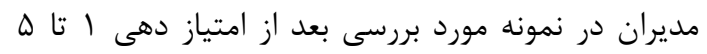

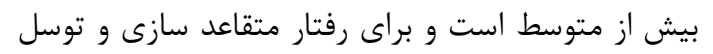

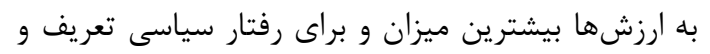

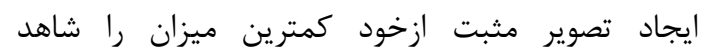

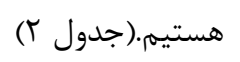

بر اين اساس در مجموع به درصد نمونه مورد بررسى

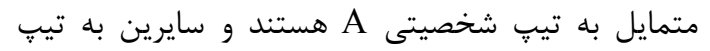
شخصيتى B بيشتر تمايل دارند. براى بررسى رابطه

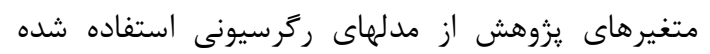

نهايتا يرسشنامه استاندارد TQ سوالى متين زارعى براى بررسى تيبٍ شخصيتى استفاده شده است.

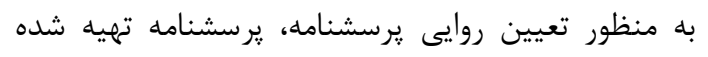
توسط يزوهشكر، جهت اظهار نظر در اختيار اساتيد محترم

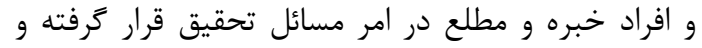

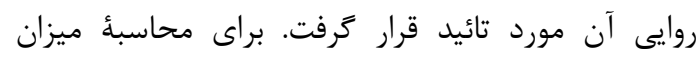

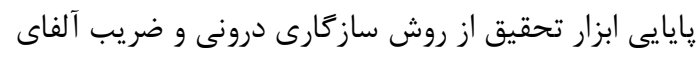

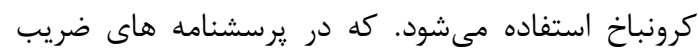
آلفاى كرونباخ در تمامى ابعاد از VD/ • بيشتر بوده بنابراين

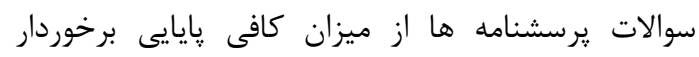

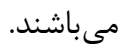
در تحليل اطلاعات بدست آمده در اين تحقيق با تفكيك تحليلها براساس فرضيات به شكل مطلوبترى به به بيان

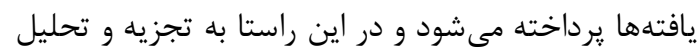

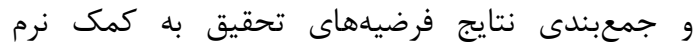

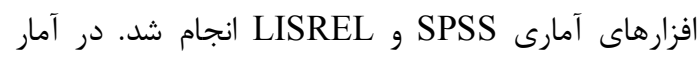

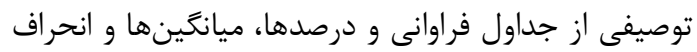

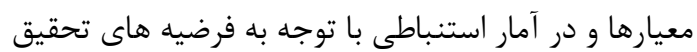

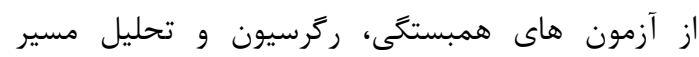

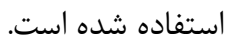

\begin{tabular}{|c|c|c|c|c|c|c|}
\hline شهروندى رفتار ضد & يرخاشكَىى & كينه توزى & طفره رفتن از & مقاومت در & لجبازى & \\
\hline$r|\wedge|$ & $r / 9 \mu$ & r/Ar & $r / \cdot 1$ & $r / 9 T$ & $r / 9 V$ & ميانخين \\
\hline$\cdot / \mu F$ & $.18 T$ & .181 & •/Ar & .109 & $1 / \cdot 9$ & انحراف معيار \\
\hline
\end{tabular}

جدول : شاخصهاى توصيفى مربوط به رفتار سياسى

\begin{tabular}{|c|c|c|c|c|}
\hline سرزنش و تهديد & همدلى & توسلبه ارزش هازى و & مشورت & شاخصما ابعاد رفتار سياسى \\
\hline$\Gamma / \Delta \cdot$ & $r / 9 \Delta$ & $r / 90$ & $r / \cdot r$ & ميانگين \\
\hline r & $\cdot / V \Delta$ & $\cdot / \Delta F$ & $.19 \mathrm{~V}$ & انحراف معيار \\
\hline رفتار سياسى & تصويرمثبتازخوايجاد & برخورد مبهم و ينهان & بايكاه حمايتى & شاخصها \\
\hline سז/ץ & T/AV & $r / r q$ & $r / v \Delta$ & ميانگين \\
\hline$\cdot / r \Lambda$ & $1 / \cdot r$ & $\cdot / V \Delta$ & $\cdot / 4 \lambda$ & انحراف معيار \\
\hline
\end{tabular}


جدول rا: ركرسيون سلسه مراتبى رفتار ضد شهروندى و رفتار سياسى

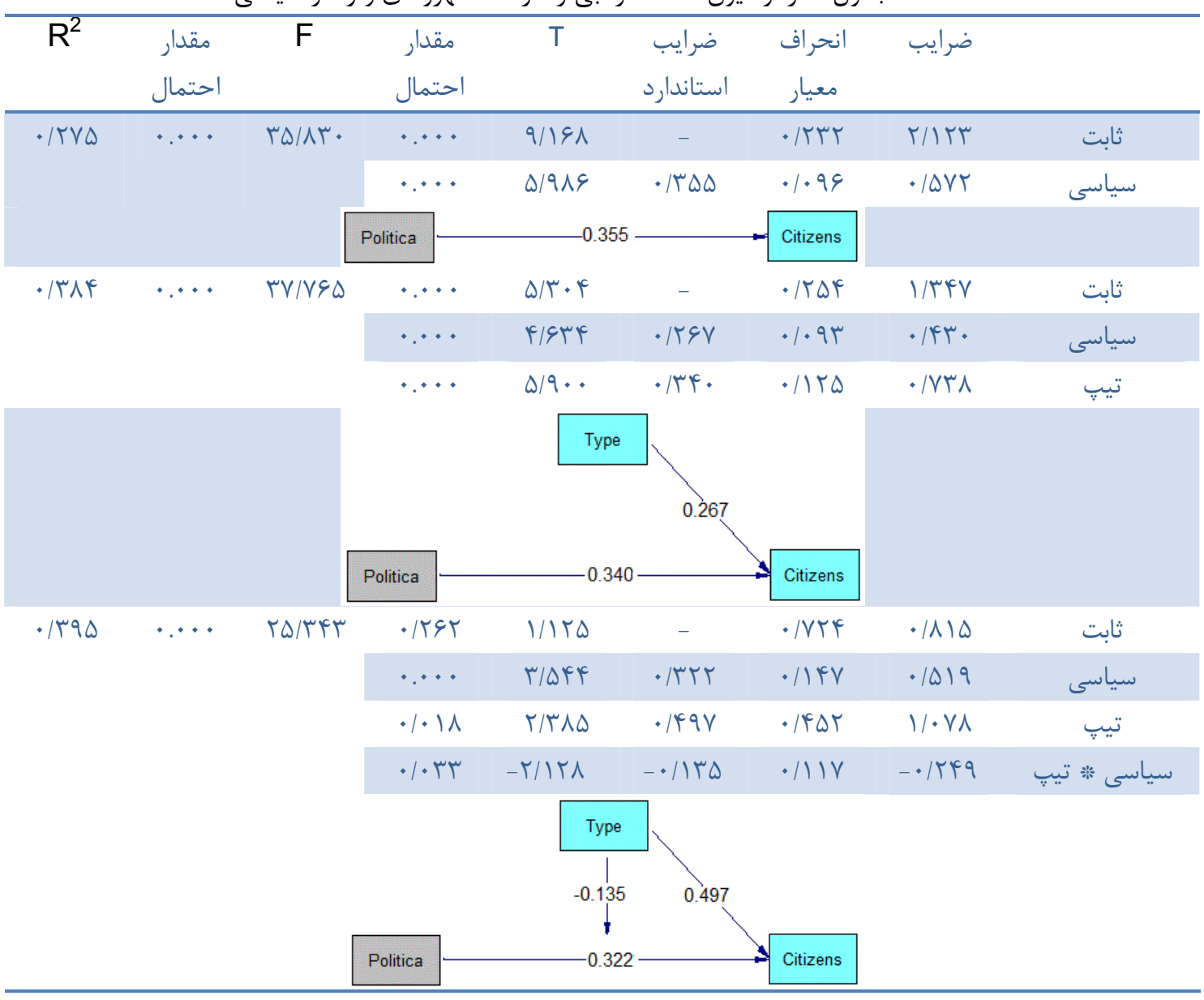

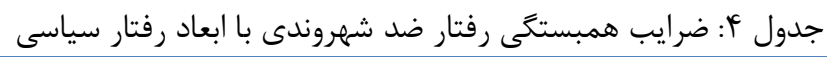

\begin{tabular}{|c|c|c|c|c|}
\hline سرزنش و تهديد & همدلى & توسل متقاعدسازى ورزشها & مشورت & \\
\hline$\cdot / r \Delta F$ & $-.1 .9 \mathrm{~V}$ & .1190 &.$/ 11 f$ & ضريبهمبستكى \\
\hline$\because \cdots$ &.$/ 1 T A$ & $.1 \cdot 1$ & $\cdot / \cdot v f$ & مقدار احتمال \\
\hline رفتار سياسى & تصويرمثبتازخود تعبيجاد & برخورد مبهم و ينهان & ֶايڤاه حمايتى & \\
\hline - MFT & $-\cdot 1 \cdot v \Delta$ & - ITFD & . Tra & ضر يبهمبستگى \\
\hline$\because \cdots$ & . 1 rMq & $\cdot \cdots$ & $\cdot \cdots$ & مقدار احتمال \\
\hline
\end{tabular}




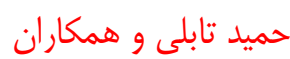

شهروندى كاركنان مىشود، تيب شخصيتى نيز به عنوان

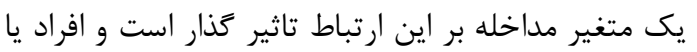

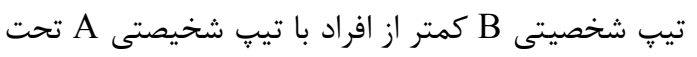

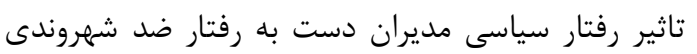

مىزند. براى يافتن موثرترين رفتارهاى سياسى بر رفتار ضد

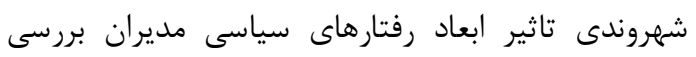

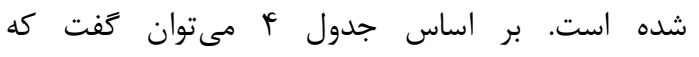
متقاعدسازى و توسلبه ارزشها، سرزنش و تهديد، رِايگاه

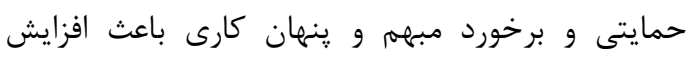
رفتارهاى ضد شهروندى مديران مى شوند.

\section{بمث}

رضايت شغلى كاركنان، توسعه سازمان از اهميت بالايى

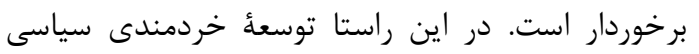

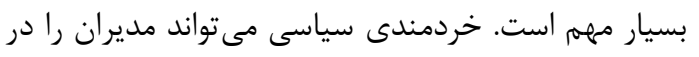

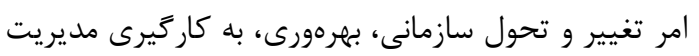

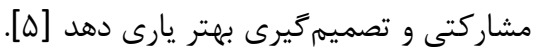

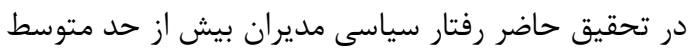

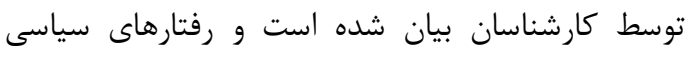

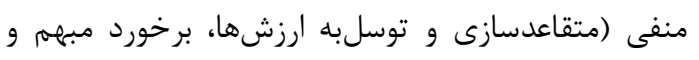

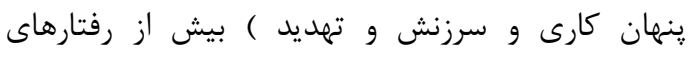

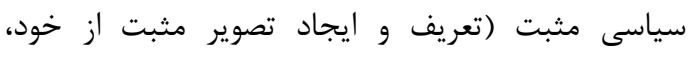
همدلى و مشورت) توسط كاركنان در مديران ديده شده

در كنار آن مىتوان ديد كه طفره رفتن از كار و مقاومت

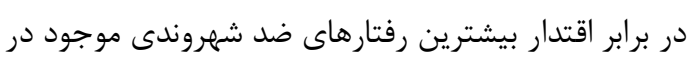

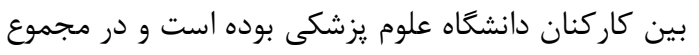

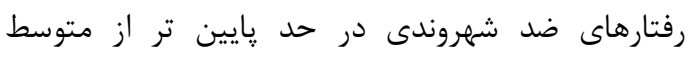

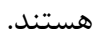
بر طبق نظر ماديسون' و همكاران [ع]، با مطالعهُ ادراى

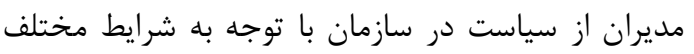

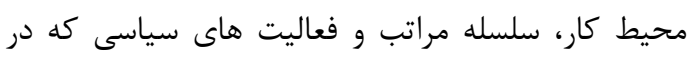

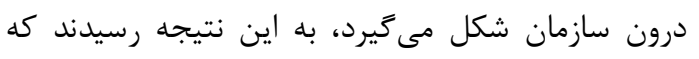

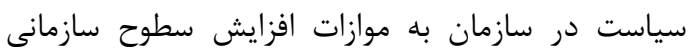
افزايش مىيابد.

\section{1- Madison}

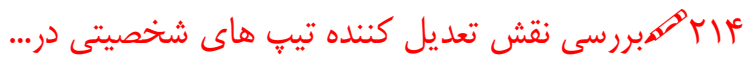

است كه در اين مدلهاى علاوه بر بررسى اثر رفتار سياسى مديران بر رفتار ضد شهروندى كاركنان تاثير تعديل كننده تيب شخصيتى نيز بررسى شده است.

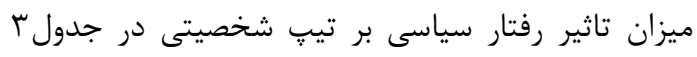
مشخص شده است. براى بررسى اين سوالات و تشخيص تعديل كر بودن آنات

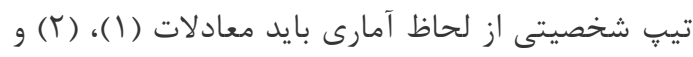
(ז) رَرسيون برآورد شوند.

1) $y=a+b_{-} x$;

2) $y=a+b_{1} x+b_{2} z_{i}$

3) $y=a+b_{1} x+b_{2} z+b_{3} x \cdot z$ كه y متغير وابسته (رفتار ضد شهروندى) و X متغير مستقل (رفتار سياسى) و Z متغير تعديل كننده (تيڤ شخصيتى) مى باشد. در صورت معنى دار بودن معادله اول ميتوان يذيرفت كه رفتار سياسى بر رفتار ضد ضد شهروندى موثر است. بر اين اساس اگر معادلات دوم و

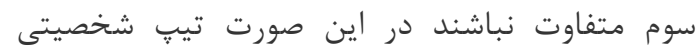

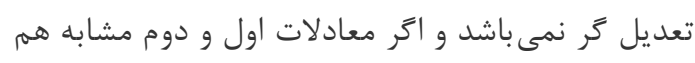

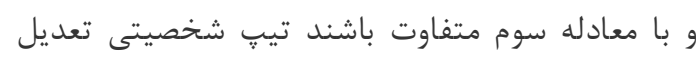
گر است و اگر تمامى معادلات متفاوت باشند تيثِ شخصيتى شبه تعديل گر است

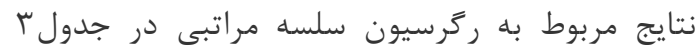

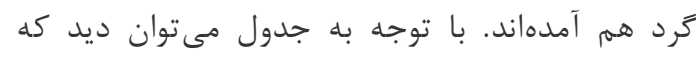

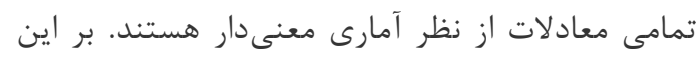

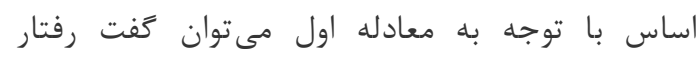

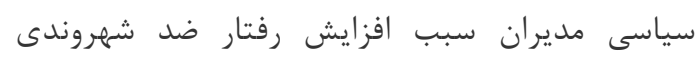

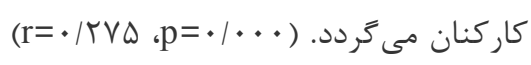

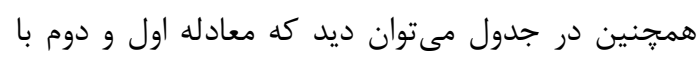
يكديخر تفاوت دارند(00

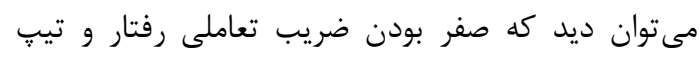

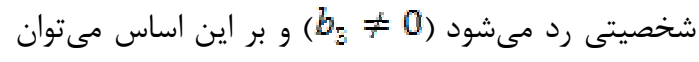

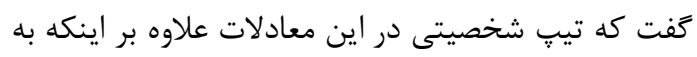

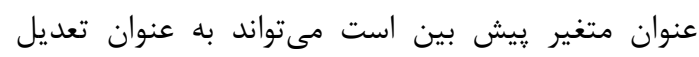

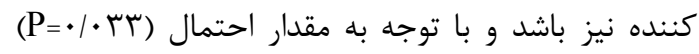

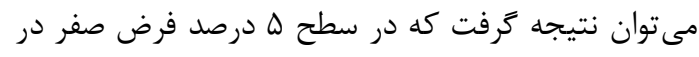

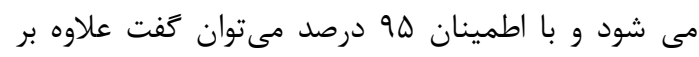

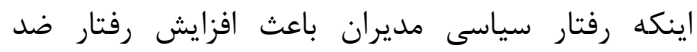


به اعتقاد علوى [V] بين رفتار سياسى و ارتقاى شغلى بران

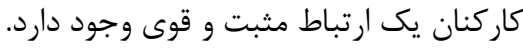

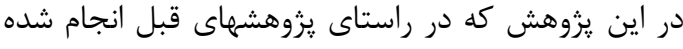

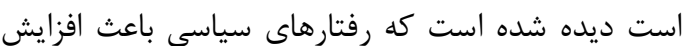

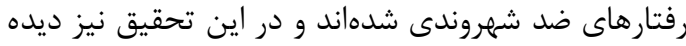

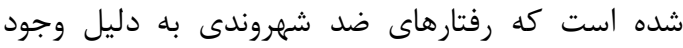

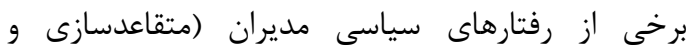

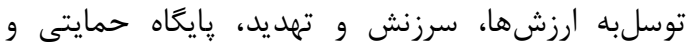

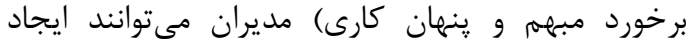

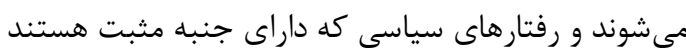
بر رفتار هاى ضد شهروندى كار كنان موثر نيستند.

نتيجه تيرى نيان

با توجه به مسائل ذكر شده فوق مديران مى توانند با توجه

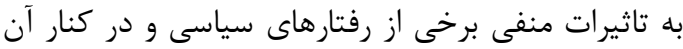

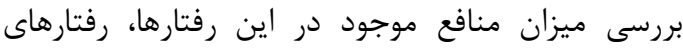

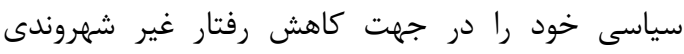

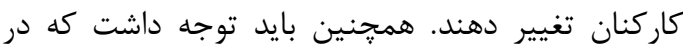

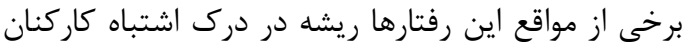

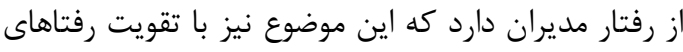

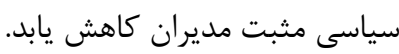
تشكر و قدر دافى مانى از كليه همكاران ستاد مركزى دانشكاه علوم يزشكى مشهد

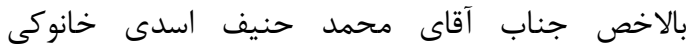
كارشناس مسئول كروه تحليل اطلاعات معاب معاونت توسعه

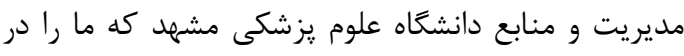
انجام اين يزوهش يارى رساندند. كمال تشكر را دارم. 


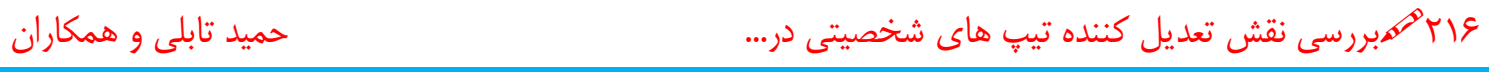

References

1. Daft.L.R.(1992), "Theory and organizational design", Cultural Research Bureau.

2. Ball G. A., Trevino L. K., \& Sims Jr., H. P. (1994), "Just and unjust punishment: Influences on subordinate performance and citizenship", Academy of Management Journal, 37(2): 299 - 318.

3. Organ,DW.(1988) Organizational citizenship behavior: "The good soldier syndrome",Lexington, MA: Lexington Books.

4. Laranc a(1991), Psychology of Personality, translation Javadi.M, Resa Publishers, Tehran.

5. Zareematin.H (2000)" political behavior avd its role in the organization and management," Journal of mojtamee Aliee Qom[Persian].

6. Madison,D.1,(1980) Organizational Politics: An Exploration of Managers' Preceptions, Human relations, 33(2), 79-100.

7. Alavi A,(1991) Organizational Politics. Meraj Publishers[Persian].

8. Ferris, G. R. \& King, T. R. (1991), Politics in human resources decisions: A walk on the dark side, Organizational Dynamics, 20 (2):59-71.

9. Perrewe, P. L. \& Nelson, D. 1. (2004),Gender and Career Success:The Facilitative Role of Political Skill, Organizational Dynamics, 33(4): 366-378 


\title{
Examine the personality type as a moderator variable in the relationship between the managers' political behavior and the anti-citizenship behavior of staff in MashhadUniversity of Medical Science.
}

\author{
Taboli $H^{l}$, Reihany Yasavoli $A^{2} *$ \\ ${ }^{1}$ Associated Professor, Management Department, Payame Noor University (PNU) \\ ${ }^{2}$ Ph.D Student in Human Resources Management, Management Department, Azad \\ University of Kerman, Kerman, Iran \\ * Corresponding Author: Azad University of Kerman, Kerman, Iran \\ Email: Reihanyya1@mums.ac.ir
}

\section{Abstract}

Background \& Objectives: University of Medical Sciences is one of the most important organs of service to the citizens. Its main purpose is to provide services and meet the needs of citizens. The investigation of anti-citizenship behavior of staff and its relationship with the managers' way of political behavior and, ultimately, the roots of problems, Could provide a better service and deserve to the citizens.

Material \& Methods: The present study is descriptive (correlation analysis), and in terms of the purpose, it is practical. This study aimed to investigate the role of moderator of the type of personality in the relationship between the managers' political attitudes and anti-Citizenship's behaviors of employees of Mashhad University of Medical Sciences. According to statistics in 1393, the total number of employees is 750 people, among which 250 people with formula samples were selected by the researchers. The survey questionnaire was used to collect information. Then, by using SPSS and LISREL software, the data were analyzed by the researchers.

Results: Political behavior of the managers increased the anti-Citizenship behaviors of employees. ( $p=0 / 000 \quad r=0 / 275)$. In addition, types of the personality can adjust the relationship between political attitudes and behavior of managers. $P(0 / 030)$.

Conclusions: The study showed that there is a relationship political behaviors of the managers and anti-Citizenship behaviors of staff. In other words, the political behavior of managers increases anti-Citizenship behaviors of staff. Among the political behavior of managers, dimensions of persuasion and appeal to values, blaming, threatening, supportive base hits and obscure secrecy had the greatest impact on anti-Citizenship behaviors of staff. Moreover, the results showed that the types of personality, as an intervening variable, affect the relationship. And those with type $B$ personality lower than those with type A, engage less to the anticitizenship behaviors.

Keywords: political behavior of managers, anti-citizenship behavior of employees, the type of personality 